\title{
Norbert Żaba - Polityka z oddali
}

Autor artykułu przyjmuje perspektywę mikrohistoryczną. Na przykładzie Norberta Żaby, polskiego uchodźcy w Szwecji w latach 1945-1994, zajmuje się problemem obowiązków emigranta wobec kraju pochodzenia w sytuacji łączności z dawną ojczyzną i zarazem częściowej alienacji od spraw polskich. Twierdzi, że Żaba należał do tak zwanych aktorów transformacyjnych, przyczyniał się do poszerzenia horyzontów poznawczych przybyszów z kraju i tym samym do wyłaniania się demokratycznej wspólnoty społeczno-politycznej w Polsce. Analiza uwzględnia problematykę taktyki działania, przywództwa, konfliktu, tożsamości grupowej, motywacji, emocji emigranta politycznego, mediów społecznych, polityki na odległość.

Słowa kluczowe: zimna wojna kulturowa, emigracja polityczna, literatura zakazana w PRL-u, kontakty Polska-Szwecja, Norbert Żaba, Jerzy Giedroyc, Adam Rudzki

This is a bibliographical study on Norbert Żaba, Stockholm-based Polish exile in Sweden after 1945 and distributor of emigre literature to visitors from Poland. As this literature was considered subversive and banned by the Polish government, Żaba's activity took the form of smuggling books through the so-called Iron Curtain. Sowinski argues that Żaba was a prime example of "activists beyond borders" (Keck \& Sikkink, 1998). During the Cold War these middle men contributed to the process of undermining the communist regimes in Eastern Europe by reinforcing and co-creating the underground book scene. Żaba could be seen, then, as a soft agent in the process of regaining freedom in Poland and in the dynamics of 1989. The scholarship includes problems such as tactics of the smugglers, leadership, inner clashes, group identity, motivations and emotions of political diaspora members, media and "politics from afar".

Keywords: cold war, political emigration, Polish-Swedish relations, Norbert Żaba, Jerzy Giedroyc, Adam Rudzki

\footnotetext{
${ }^{1}$ Kontakt: sowinski@isppan.waw.pl
} 
Wielu emigrantów nie traci łączności z krajem swojego pochodzenia, mogą niekiedy wręcz umacniać świadomość odrębności narodowej, odegrać rolę w transformacji ustrojowej ich dawnych ojczyzn ${ }^{2}$. Zdaniem rzeczników takiego podejścia narastająca globalizacja przyśpiesza przemiany polityczne. We współczesnym świecie zawiązują się sieci, które coraz słabiej złączone są z jednym terytorium. Ich uczestnicy mogą współdziałać na dużą odległość, nie znając się nawzajem³. Obserwacje te mają jednak również historyczne antecedencje, o czym przekonują listy osobiste Norberta Żaby (1907-1994), emigranta polskiego w Szwecji.

Przebadana twórczość epistolograficzna liczy 325 listy, z tego 104 listy wymieniane z Jerzym Giedroyciem w latach 1960-1994 (w zbiorach Instytutu Literackiego pod Paryżem) oraz 221 listy (z International Literary Centre w Nowym Yorku) kontakty przeważnie z Adamem Rudzkim w latach 1972-1990. Korespondencja Żaba-Giedroyc bliska jest konwencji listów prywatnych. Wprowadzają w kulisy działalności emigracyjnej, informują o wewnętrznych problemach emigrantów politycznych, ukazują ich rozterki, sympatie, niechęci, sposoby myślenia. Z kolei korespondencja Żaby z Rudzkim, która miała głównie charakter służbowy, stanowi jeden z najlepiej zachowanych przykładów powiązań emigracyjnych kolporterów ze Stanami Zjednoczonymi. Liczna korespondencja Żaby nie daje pełnego wglądu nawet w jego własne życie. Opisy środowiska, w jakim się obracał, siłą rzeczy były jeszcze bardziej wybiórcze. Wielu informacji z listów nie sposób też potwierdzić w innych źródłach ${ }^{4}$.

Na historycznych przekazach zazwyczaj ciąży dążność ich autorów do autoprezentacji, ukazywania własnej osoby w korzystnym świetle, koncentrowania się na sprawach, które akurat pasjonują piszących ${ }^{5}$. Listy to świadectwa na ogół sporządzane „na gorąco”, wyrażające emocje chwili. Jednak Żaba, Giedroyc i Rudzki pisali do siebie w okresie dojrzałym. W latach 80 . XX wieku byli już osiemdziesięciolatkami, którzy w życiu przeszli niejedno. Z tej racji dysponowali szerszą perspektywą oceny zjawisk i potrafili zdystansować się od bieżących wydarzeń. Wybór jednostkowej perspektywy badań oddala moje rozważania od socjologii, zbliża

2 M. Kula (2003), Narody a migracje: esej z socjologii historycznej, „Studia Migracyjne - Przegląd Polonijny", z. 2, s. 5-13.

3 T. Lyons, P. Mandaville, (2012), Introduction, w: Lyons, T., Mandaville, P. (red.), Politics from Afar: Transnational Diasporas and Networks, London: Hurst and Company, s. 1-23; L. Basch, N. Glick Schiller, C. Blanc Szanton (1994), Nations Unbound. Transnational Projects, Postcolonial Predicaments, and Deteritorialized Nation-States, London: Routledge.

${ }^{4}$ Więcej na temat listów osobistych jako źródła historycznego, tradycji badań takich dokumentów, w: W. Kula, N. Assorodobraj-Kula, M. Kula (2012), Wstęp w: Kula W., Assorodobraj-Kula N., Kula M. (red.), Listy emigrantów z Brazylii i Stanów Zjednoczonych 1890-1891, Warszawa: PWN, s. $25-120$.

${ }^{5}$ Więcej na temat epistolografii Jerzego Giedroycia i sposobach jej interpretacji w: A.St. Kowalczyk (2006), Od Bukaresztu do Laffitów. Jerzego Giedroycia rzeczpospolita epistolarna, Sejny: Fundacja Pogranicze, s. 7-13. 
zaś do antropologii historycznej. Narracyjna, opowieściowa metoda prezentacji materiału bliska jest historii. Głównym bohaterem nie są jednak instytucje - ich rozliczne instancje, formalne praktyki. Podmiotem opracowania jest człowiek ze swoim subiektywnym spojrzeniem na zachodzące wokół niego procesy.

Analiza jednego przypadku wyklucza możliwość generalizacji i niewiele mówi o szerszych procesach. Taka perspektywa jednak pozwala wydobyć różne szczegóły, które łatwo umykają uwadze w studiach o większym zasięgu, kontekstualnych obudowach tematu itp. Dlaczego stawiam w centrum uwagi właśnie los Żaby, a nie innego emigranta? Jest to subiektywny wybór, oparty o znajomość innych postaci z kręgu wydawców i kolporterów emigracyjnych ${ }^{6}$. Żaba to jeden z najlepiej udokumentowanych przypadków emigracyjnego pośrednika kulturowego między światem Zachodu a Wschodu. Działalność tego rodzaju nauka nazywa kulturową dyplomacją. Żaba i jemu podobni wchodzą w rolę często zarezerwowaną dla tradycyjnej polityki zagranicznej, aparatów państwowych i ambasad ${ }^{7}$. Studium może okazać się pomocne w budowie modelu funkcjonowania polskiego emigranta tamtych czasów, kolportera wydawnictw nieaprobowanych w PRL-u.

Żaba przez lata prowadził swoją misję na ulicy Kallskärsgatan $3 \mathrm{w}$ Sztokholmie, $w$ jednopokojowym mieszkaniu, w bloku na czwartym piętrze, w kapryśnym, chłodnym klimacie Skandynawii. Nie miał biura, sekretarki ani nawet samochodu. Ciasna przestrzeń i brak udogodnień wciąż utrudniały jego aktywność. Wśród przyjezdnych z PRL-u znany był jako dystyngowany jegomość w garniturze, który rozdawał zakazany w kraju miesięcznik „Kultura” i książki Jerzego Giedroyciå . Miał ich pełną piwnicę. Niemal codziennie chodził na pocztę. W starszym wieku, za drobną opłatą, pomagali mu dźwigać pakunki ludzie młodzi. Trwał na swoim posterunku ponad trzydzieści lat. Rola Żaby polegała na przedłużeniu szlaku emigracyjnej książki w głąb bloku wschodniego. Łączył Szwecję z Polską dzięki kontaktom międzyludzkim, ale również możliwościom handlu i transportu morskiego, jakie dawał Sztokholm? .

Urodził się 13 lipca 1907 roku w Tallinie, wówczas zwanym Rewalem, w rodzinie wywodzącej się ze starej szlachty inflanckiej - polsko-litewskiej pochodzenia ruskiego. Słownik geograficzny Królestwa Polskiego podaje, że jego przodek Borys Żaba - bojar Dumy Smoleńskiej i żołnierz w służbie Stefana Batorego - brał udział

${ }^{6}$ P. Sowiński (2016), Tajna dyplomacja. Książki emigracji w drodze do Polski 1956-1989, Warszawa: Wydawnictwo Więź, Instytut Studiów Politycznych PAN.

${ }^{7}$ M. Keck, K. Sikkink (1998), Activists beyond Borders: Advocacy Network in International Politics, Ithaca: Cornell University Press.

${ }^{8}$ J. Korek (2007), Norbert Żaba i „niewidzialna redakcja” o całkiem konkretnych zadaniach (zarys problematyki), w: Hofman I. (red.), Kultura paryska. Twórcy, dzieło, recepcja, Lublin: Wydawnictwo Uniwersytetu im. Marii Curie-Skłodowskiej, s. 39-53. Artykuł Korka jako pierwszy zwraca uwagę na rolę Żaby i umieszcza tę postać w kręgu najbliższych współpracowników paryskiej „Kultury”.

9 T. Griffiths (2009), Stockholm. A Cultural History, Oxford: Oxford University Press; M. North (2016), The Baltic. A History, Cambridge: Harvard University Press. 
w zdobyciu Dyneburga nad Dźwiną i przyłączeniu go - jak się później okazało - na trzy wieki do Rzeczypospolitej. W 1601 roku Borys w nagrodę dostał od Zygmunta Wazy majątek w pobliżu Dźwiny, który pozostał w rękach Żabów aż do 1918 $\mathrm{roku}^{10}$. Rodzina matki pochodziła ze Szwecji. W XVIII wieku migrowała do Estonii, która była wówczas częścią Szwecji - i szybko się zestonizowała. Matka Klara, z domu Oklon, luteranka silnie osadzona w kulturze niemieckiej, wychowywała jednak syna w wierze katolickiej. W domu mówiło się głównie po rosyjsku. Ksiądz katolicki w Tallinie nie znał polskiego. Nauka religii odbywała się po niemiecku. W szkole Żaba był jedynym katolikiem i jednym Polakiem.

\section{Przerwana kariera}

Gdy Norbert skończył siedem lat, rodzice wysłali go do Obabia (dzisiaj Białoruś), majątku rodzinnego, by uczył się polskiego. W czasie pierwszej wojny światowej jego nauczycielami polskiego byli dwaj żołnierze armii rosyjskiej. Uważał się już wówczas za Polaka, ale to nadal wzbudzało niedowierzanie. „Da, kakoj ty Polak, ty po polski nie goworisz" - dziwili się oficerowie. Norbert przemieszczał się wraz ze swoim ojcem Julianem, rosyjskim oficerem, po garnizonach carskich. Przybywał przez pewien czas w Jamburgu (dzisiaj Kingisepp), w Finlandii, a potem w Twerze nad Wołgą, gdzie za czasów premiera Aleksandra Kiereńskiego jego ojciec dowodził trzema pułkami. Mieszkali wówczas w skrzydle dawnego pałacu cesarzowej Katarzyny. Żaba zaczytywał się tam w literaturze rosyjskiej i bawił się w ogromnym pałacowym parku. Stangret woził go codziennie do gimnazjum saniami zaprzęgniętymi w dwa siwe konie. Żaba przeżył w Rosji obie rewolucje. Po latach napisze, że właśnie to doświadczenie wpłynęło najbardziej na jego postrzeganie komunizmu, niewiarę w możliwości jego reformy ${ }^{11}$.

Po wybuchu rewolucji bolszewickiej w listopadzie 1917 roku ojciec Norberta zdezerterował z armii rosyjskiej i zabrał żonę oraz syna do Estonii. Stamtąd pojechali „do Piłsudskiego”, pomagać w budowaniu Polski. Ojciec walczył na wojnie z bolszewikami. Sześć lat później, jako zastępca dowódcy pułku, poparł zamach majowy Piłsudskiego. „Za co ciotka moja Zofia z imienin za drzwi go wyrzuciła” - wspominał wiele lat później Norbert Żaba w liście do Jerzego Giedroycia ${ }^{12}$. W latach dwudziestych XX wieku Żaba skończył niemieckie gimnazjum w Tallinie.

${ }^{10}$ F. Sulimierski, B. Chlebowski, W. Walewski (1886), Słownik geograficzny Królestwa Polskiego i innych krajów słowiańskich, t. 7, s. 316, Warszawa: Kasa im. Józefa Mianowskiego. Zob. także życiorys Żaby w jego papierach wysłany do Jerzego Giedroycia (około połowy lat 70. XX w.). Archiwum Akt Nowych (dalej: AAN), akta Norberta Żaby.

${ }_{11}$ Życiorys Żaby, ibid. Podstawowe dane biograficzne odtworzył już Janusz Korek na podstawie papierów Żaby. J. Korek, Norbert..., s. 43-45.

${ }^{12}$ Listy Żaby do Giedroycia (31 stycznia 1988), Korespondencja Żaba-Giedroyc, Archiwum Instytutu Literackiego pod Paryżem (dalej AIL). 


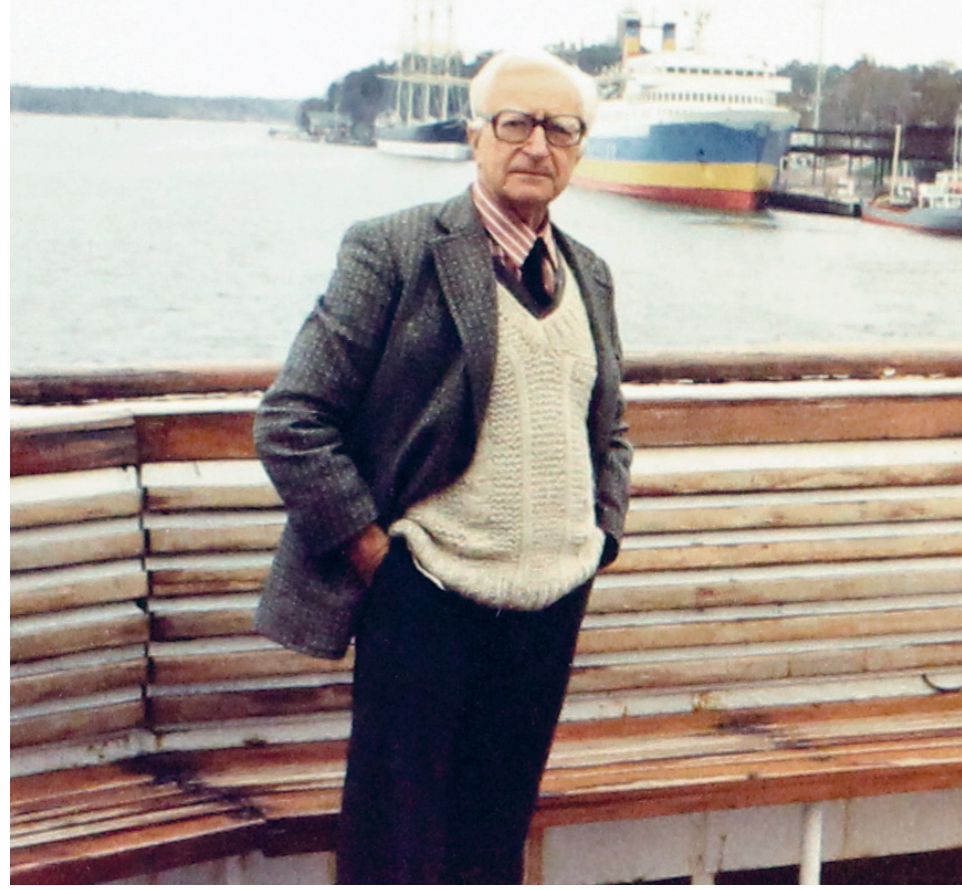

1. Norbert Żaba, Sztokholm, data i autor nieznane, akta Norberta Żaby w Archiwum Akt Nowych w Warszawie.

Potem pojechał na wyższe studia handlowe do Wiednia (1926-1929). W swoich pierwszych wyborach, pod wpływem ciotek, głosował jeszcze na endecję, później już na sanację. Krótko pracował w Warszawie, potem przeniósł się do Wilna, gdzie na emeryturze osiadł jego ojciec. Norbert zaczął pisać do „Słowa” (do dodatku młodzieżowego), pisma wileńskich konserwatystów. Wkrótce potem żartował o swojej inicjacji politycznej: „jak pisze pismo święte, przybyło do Wilna dwóch mędrców, jednemu na imię było Rowmund Piłsudski a drugiemu Jerzy Giedroyc"13.

W 1933 roku przystąpił do konserwatywnej Myśli Mocarstwowej, organizacji akademickiej o elitarnym zasięgu, której liderem był Giedroyc. Podobała mu się wówczas idea polskiej mocarstwowości, promowana coraz wyraźniej przez obóz władzy. Rozumiał ją jako powrót do Polski jagiellońskiej, kresowej, jako odnowienie wielonarodowościowej I Rzeczypospolitej. To przeświadczenie o wadze i wyjątkowości Polski opierało się na iluzjach, wierze w możliwość powrotu do

${ }^{13}$ J. Korek, Norbert..., s. 43-45. 
przeszłości, jakby na przekór współczesnym realiom - rosnącym aspiracjom narodowościowym i państwowym ludów dawnej Polski. Inicjatywa grupowała młodych konserwatystów, bliskich ideowo sanacji ${ }^{14}$. Związki Żaby z tym obozem przypieczętował angaż do służby dyplomatycznej, w której w pełni mógł wykorzystać swoje talenty językowe (m.in. znajomość fińskiego i estońskiego). W latach 1935-1938 roku pracował jako attaché prasowy w ambasadzie RP w Helsinkach ${ }^{15}$.

Wojna zastała go na stanowisku zastępcy biura Polskiej Agencji Telegraficznej w Berlinie. We wrześniu 1939 udał się do Kopenhagi, by w kwietniu 1940 roku łódką przez cieśninę Sund uciekać do Szwecji. Tam zasilił personel ambasady polskiej w Sztokholmie ${ }^{16}$. Szwecja miała stać się jego domem aż do śmierci. Nie wiemy, jak przeżywał wczesną emigrację i nagłe rozdzielenie z rodziną ${ }^{17}$. Po wojnie uprawiał dziennikarstwo. Do 1956 roku Żaba pracował w Sztokholmie jako korespondent do spraw wschodnich „Daily Mail” i Reutera. Pisywał również do prasy szwedz$\mathrm{kiej}^{18}$. Po 1956 roku - wraz z otwarciem się bloku wschodniego na dziennikarzy zagranicznych - stracił pozycję i dochody w prasie europejskiej, gdyż media zachodnie chciały mieć swoich wysłanników na miejscu, a on do Polski jeździć nie chciał. W tej sprawie prezentował poglądy bliskie nieprzejednanym emigrantom z Londynu, którzy stali na stanowisku nieuznawania PRL- ${ }^{19}$.

\section{Hotel Pharos}

Rok 1956 przyniósł jednak emigracji nowe możliwości oddziaływania na kraj. Pod koniec lat pięćdziesiątych XX wieku Żaba odnowił kontakt z Jerzym Giedroy$\mathrm{ciem}^{20}$. Od 1958 roku dorabiał w szwedzkiej turystyce jako przedstawiciel biur podróży w krajach basenu Morza Śródziemnego. Gdy jechał z wycieczkami do Chorwacji, zawsze zabierał walizkę paryskiej „Kultury” dla turystów z Polski. Wieczorami przechadzał się po porcie w Hvarze, starając się spotkać polskich żeglarzy

${ }_{14}$ W. Władyka (1977), Działalność polityczna polskich stronnictw konserwatywnych $w$ latach 1926-1935, Wrocław: Zakład Narodowy im. Ossolińskich; M. Żebrowski (2012), Jerzy Giedroyć. Życie przed „Kulturą”, Kraków: Wydawnictwo Literackie.

${ }^{15}$ Więcej na temat helsińskiego epizodu z życia Żaby w: Z. Braczyk (1994), Życie na złączach. Ze wspomnień Norberta Żaby, „Acta Sueco-Polonica” nr 3, s. 217-226.

${ }^{16}$ Z. Braczyk (1991), Pochwała inności. Z Norbertem Żaba, przedstawicielem „Kultury” w Sztokholmie rozmawia Zygmunt W. Braczyk, „Tygodnik Powszechny”, nr 16.

${ }_{17}$ Matki, jak się wydaje, już nigdy nie zobaczył. W latach 50. XX w. pisał do niej listy, których kopie znajdują się w aktach IPN. Sprawa Dziennikarz i Meduza, Archiwum Instytutu Pamięci Narodowej (dalej: AIPN) 0204/275.

18 Życiorys Żaby w aktach Norberta Żaby, AAN.

19 A. Friszke (1999), Życie polityczne emigracji, Warszawa: Wydawnictwo Więź.

20 Trudno określić, kiedy Żaba zaczął korespondować z „Kulturą”. Pierwszy zachowany list Żaby do Giedroycia pochodzi ze stycznia 1960 roku; zawarte w nim informacje wskazują na ich wcześniejsze kontakty listowne. 
cumujących na nadbrzeżu. Pewnego razu latem 1970 roku, kiedy miał już wejść do morza, by się wykąpać, nagle dostrzegł w ciemnościach dwa jachty. Polacy od razu zaoferowali mu zakup kryształowego wazonu. Kupił go od nich - jak twierdził, przepłacając - oni zaś w zamian obiecali mu zabrać książki rosyjskich dysydentów Andrieja Amalrika i Aleksandra Sołżenicyna do biblioteczki pokładowej. Pomógł im jeszcze w „upłynnieniu” drugiego kryształu w Hvarze. Ku jego zaskoczeniu pewna załogantka „Z radością chwyciła „Kulturę”, narzekała na trudności paszportowe, ale $\mathrm{w}$ rozmowie okazała się również wielbicielką reżimu komunistycznego. Broniła wyrzucania Żydów z Polski w 1968 roku - „zupełnie nieczuła na krzywdę cudzą, za to wrażliwa na własną"21.

Żaba powoli zdobywał sympatię Polaków w Jugosławii, a polskie jachty docierające nad Adriatyk zabierały „Kulturę”. Zapraszał kolejne załogi na dalmatyńskie wino deserowe i drobny poczęstunek. Dla turystów z Polski stanowiło to pewną atrakcję, jako że posilali się oni często wyłącznie żywnością z konserw przywiezionych z kraju. „Pariasi turyzmu - ludzie głodni wiedzy, kontaktu ze światem, ale bez pieniędzy” - dzielił się wrażeniami z Giedroyciem. „Żeglują w nocy, za dnia zwiedzają"22. Żaba rozdał im wszystkie egzemplarze „Kultury” i prosił Giedroycia o dosłanie nowych porcji. W sprawozdaniach Żaby ze spotkań z Polakami niekiedy pobrzmiewał ton wyższości - człowieka swobodnie poruszającego się po Europie, znającego języki, mogącego pozwolić sobie na hojność wobec niezamożonych i trochę zagubionych rodaków.

Przygodny kolportaż „Kultury” w warunkach plażowych odbywał się bez przeszkód, gdyż Żaba nie miał zbyt dużo kłopotów ze szwedzkimi turystami, którymi formalnie musiał się opiekować. Wykorzystał też efekt zaskoczenia - polscy celnicy nie podejrzewali, że „Kultura” będzie przemycana do Polski z socjalistycznej Jugosławii. Warto jednak zastrzec, że dostępne nam źródła prezentują jedynie optykę emigrantów. W latach 1967-1973 Żaba przebywał w hotelu Pharos zawsze od czerwca do października. Pewnego dnia na prośbę Hvarskiego Biura Turystyki oprowadzał polską wycieczkę po wyspie. „Na moje pytanie czy ktoś pragnie otrzymywać «Kulturę» i wydawnictwa paryskie, najpierw milczenie, potem nieśmiało starsza kobieta «bardzo proszę», a potem wyciągnęło się jeszcze 4-5 par rąk. Zaniosłem te książki im do portu przed odejściem statku. [...] Po drodze spotkałem inną starszą Polkę, która błagała o «Kulturę». Miałem na szczęście w rezerwie, dałem”23.

W 1971 roku Żaba rozdał jeszcze więcej egzemplarzy wycieczkom, żeglarzom, plażowiczom z Polski. Przypływały kolejne łódki. W 1971 roku było ich raptem trzy, ale ich załogi wymieniały się. Każda liczyła osiem osób. Żaba stawiał im drinki w tawernie w luksusowym hotelu Palace, w dawnej weneckiej twierdzy. Stamtąd

\footnotetext{
21 Żaba do Giedroycia (13 sierpnia 1970), AIL.

22 Żaba do Giedroycia, (12 czerwca 1970), AIL.

23 Żaba do Giedroycia (25 września 1971), AIL.
} 
przenosili się do Pharos na dalsze nocne rozmowy o Polsce. Trafiali się ludzie bardzo oczytani, większość jednak spotkała się wydawnictwami emigracyjnymi po raz pierwszy. Trzeba pamiętać, że poczucie dystansu między Polską a zagranicą było wówczas większe niż dzisiaj ${ }^{24}$. Lipcowy numer „Kultury” Żaba rozprowadził w grupie jachtowej z Krakowa. „Zaprosiłem grupę przed południem na whisky, wieczorem na kawę z likierem" - relacjonował do Paryża ${ }^{25}$. Jeden z uczestników wysuwał oskarżenia o współpracę emigracji z obcymi wywiadami, ale Żaba potrafił umiejętnie załagodzić sytuację wspomnianym poczęstunkiem w lokalu na jego koszt ${ }^{26}$.

Wówczas jeszcze kolportaż „Kultury” nie wypełniał jego czasu w tym stopniu co w latach późniejszych, gdy w 1972 roku stał się głównym dystrybutorem bezpłatnych książek w Szwecji, wydawanych z myślą o rodakach w kraju i finansowanych przez International Literary Center (ILC) - amerykański program krzewienia wolności słowa w Europie Wschodniej ${ }^{27}$. Od tego czasu spotkania z przyjezdnymi z Polski stały się jego główną aktywnością i radością życiową. Liczba rozdawanych przez niego egzemplarzy sięgnęła kilku tysięcy rocznie ${ }^{28}$. Gdy w Polsce powstała „Solidarność”, małe mieszkanie Żaby w Sztokholmie przeżywało oblężenie. Książki musiał trzymać pod łóżkiem - nie tylko ze względu na trudności lokalowe, ale również, żeby odbiorcy książek nie zabrali mu od razu wszystkich publikacji ${ }^{29}$. W listach raczej nie manifestował zmęczenia ludźmi z kraju, mimo że ich wizyty rozbijały jego rytm dnia. Niekiedy musiała nużyć powtarzalność, z jaką rozdawał książki.

Uważał jednak tę akcję za niezwykle potrzebną do budzenia antykomunistycznej świadomości. W 1977 roku apelował do Adama Rudzkiego: „Wysyłanie książek oraz azyl dla ludzi naprawdę zagrożonych to najważniejsze działania nasze. Wszelkie inne działania, jak uprawianie polityki emigracyjnej, spory o takie czy owakie ideologie, to sprawy trzeciorzędne. Książki to dynamit, są pochłaniane przez ludzi myślących, czynnych, rozszerzają grono opozycji, dają jej otuchę, co kiedyś w końcu doprowadzi na wschodzie do tego, co miało miejsce w Grecji, Portugalii, Hiszpanii. Na to nie wolno oszczędzać wydatków i sił"30. Fragment ten świadczy

${ }^{24}$ M. Kula (2010), Mimo wszystko bliżej Paryża niż Moskwy. Książka o Francji, PRL i o nas historykach, Warszawa: Wydawnictwo Uniwersytetu Warszawskiego.

${ }^{25}$ Żaba do Giedroycia (7 września 1971), AIL.

${ }^{26}$ Ibidem.

27 A.A. Reisch (2013), Hot Books in the Cold War, Budapest: CEU Press, oraz polskie wydanie (2015): Nieznany front zimnej wojny, przekł. Patrycja Poniatowska, Warszawa: Instytut Pamięci Narodowej.

${ }^{28}$ Rezydentura wywiadu PRL-u w Sztokholmie szacowała darmową dystrybucję Żaby na ok. 7 tysięcy publikacji w okresie letnim 1986 roku (na podstawie książek nadesłanych do niego z Nowego Jorku). W listach Żaby ta cyfra się nie pojawia. Porównując różne dane w papierach Żaby można uznać wyliczenia wywiadu za prawdopodobne. Meldunek w sprawie akcji przerzutu literatury ze Szwecji, 9 maja 1986, AIPN, 0449/5/74.

${ }^{29}$ List Żaby do Adama Rudzkiego (16 stycznia 1981), AAN.

30 Żaba do Rudzkiego (9 lutego 1977), AAN. 
o tym, że w drugiej połowie lat 70. XX wieku Żaba był już trwale i mocno związany $\mathrm{z}$ akcją książkową, wyznaczał dla niej cele strategiczne i długofalowe. W rozdawnictwie książek - nie w podtrzymywaniu życia politycznego emigracji - upatrywał najbardziej nadziei na demokratyzację Polski.

\section{W kręgu Giedroycia}

Znajomość Żaby z Giedroyciem wykraczała poza rutynową współpracę dwóch emigrantów politycznych w podobnym wieku. Przeszli na „ty” w 1933 roku, na początku swojej znajomości. Po wojnie widywali się bardzo rzadko, spotkania zastępował telefon i listy. Żaba, stary kawaler, mieszkający samotnie - od 1974 roku, po skończeniu 67 lat, na emeryturze - mógł poświęcić tej relacji dużo czasu. Podkreślał w listach swoje bezgraniczne przywiązanie do „Kultury” i długoletnią przyjaźn z Jerzym³ ${ }^{31}$. Cementowały ją nostalgiczne nawiązania do czasów Myśli Mocarstwowej, reminiscencje przeżyć z młodości, które okazały się ważne dla ich późniejszej więzi ${ }^{32}$. Emocjonalny związek ze sprawami przedwojennej Polski odróżniał ich od młodszej generacji działaczy emigracyjnych, podobnie jak „wielokulturowa formacja” Polski kresowej ${ }^{33}$.

Giedroyc nie był aż tak wylewny, odpowiadał zwięźle, niekiedy w formie wytycznych, ale zaliczał Żabę do grona zaufanych ludzi. Jako wierny sojusznik i kolega Giedroycia z czasów „Buntu Młodych” Żaba zajmował szczególną pozycję. Ich wybory polityczne ułożyły się podobnie, nic poważniejszego nie komplikowało ich relacji po wojnie. Janusz Korek określał grupę bliskich współpracowników mianem „niewidzialnej redakcji” miesięcznika. Żaba sam niewiele pisywał do pisma. To jednak nie zmienia jego dużej wagi jako „informatora i korespondenta” Giedroycia. Słał mu obszerne omówienia sytuacji w Polsce, skrupulatnie notował wiadomości zasłyszane od odwiedzających go w Szwecji Polaków ${ }^{34}$. Na jego przykładzie widać może najlepiej, na czym polegała codzienna kulturowa dyplomacja emigrantów politycznych. Żaba nie potrafił wyjść z roli dyplomaty. Sporządzał swoje sprawozdania tak, jakby Giedroyc był przedwojennym MSZ, nie bacząc na to, że obaj w żadnym ministerstwie nie pracowali już od wielu lat.

Ze względu na znajomość kilku języków i szerokie kontakty Żaba zbierał informacje z różnych stron - ze Szwecji, Finlandii, od polityków, dziennikarzy, szwedzkiej policji. Bywał lepiej poinformowany niż peerelowski ambasador w Sztokholmie. „Żaba ma najlepsze kontakty międzynarodowe spośród wszystkich działaczy

31 Żaba do Giedroycia (19 listopada 1988), AIL.

32 Żaba do Giedroycia (14 maja 1974), AIL.

${ }^{33}$ J. Korek, Norbert..., s. 52.

${ }^{34}$ J. Korek, Norbert..., s. 42. Korek omówił również kilka krótkich artykułów Żaby oraz tworzoną przez niego Kronikę szwedzką, która od 1977 roku ukazywała się na łamach „Kultury”. 
emigracyjnych w Szwecji” - stwierdzał wywiad PRL w notatce z 1986 roku $^{35}$. Żaba dobrze zadomowił się w Szwecji, nie czuł się tam obco. To do niego przychodzili przybysze z Polski szukający porad azylowych lub pracy sezonowej, nie mówiąc już o tych, którzy chcieli coś ciekawego przeczytać. W ten sposób tworzyły się kontakty kraj-emigracja. Choć Żaba mógł niekiedy wytwarzać dystans - młodzi postrzegali go zapewne jak przedstawiciela odległego świata Polski przedwojennej - uzyskiwane przez niego informacje świadczą o głębszym dialogu z gośćmi z Polski. Żaba potrafił dostrzegać wewnętrzne zróżnicowania wśród Polaków i dostosowywać rozmowę do rangi społecznej, pochodzenia czy miejsca zamieszkania swoich interlokutorów ${ }^{36}$.

W marcu 1980 roku Żaba gościł przez 6 godzin pracowników naukowych Instytutu Badań Literackich w Warszawie - Stefana Treugutta i Ryszarda Górskiego. Reprezentanci IBL-u przekazali Żabie prośbę - skierowaną do Giedroycia - o wydanie w Instytucie Literackim zbioru esejów i poezji Miłosza, niedopuszczanego w Polsce przez cenzurę. „Zapotrzebowanie na Miłosza jest ogromne ${ }^{37 ”}$ - twierdzili goście z Warszawy. Treugutt i Górski oceniali, że z biblioteki prohibitów IBL-u korzysta cały personel oraz jeszcze około 400 osób - studentów i literatów. Żaba dowiedział się z tej rozmowy, że rzeczywistość peerelowska jest pełna niuansów. Nawet książki, które zatrzymywali celnicy na granicach, nie zawsze ginęły. Niektóre egzemplarze miały trafiać do bibliotek partyjnych lub ministerialnych, inne do pokątnej odsprzedaży w warszawskich antykwariatach, gdzie oferowano te „zakazane” druki zaufanym klientom, m.in. docentowi Treuguttowi ${ }^{38}$.

Giedroyc z kolei powierzał Żabie swoje myśli, także te najgłębiej schowane przed innymi - niepokoje, podejrzenia, frustracje. Za przykład może służyć poufny list Giedroycia do Żaby z listopada 1982 roku w odpowiedzi na zamiar Żaby reprezentowania londyńskiego pisma „Aneks” w Szwecji. Sprawa sprowadzałaby się zapewne do przyjmowania prenumerat i sprzedaży pisma, ale redaktor widział w tym nielojalność wobec „Kultury” i postawił Żabę przed ultimatum - „Kultura" albo "Aneks"39. Żaba ugiął się przed tym niespodziewanym dictum ze strony starego przyjaciela. W tych latach Giedroyc uważał już młodych wydawców za konkurentów, którzy podkopywali jego pozycje, a nawet czyhali na przejęcie „Kultury" po jego śmierci. Po latach zachowanie Giedroycia może posłużyć za przykład,

${ }^{35}$ Meldunek o przygotowywanej w Szwecji akcji przerzutu wrogiej literatury do kraju, 9 maja 1986, AIPN 0449/5/74; Informacje dzienne MSW. Załącznik do informacji dziennej, 1 czerwca 1987, AIPN 01304/934.

${ }^{36}$ Do najciekawszych należały obserwacje w listach do Giedroycia z 17 września 1975 i 4 czerwca 1986 oraz obserwacje w listach do Rudzkiego z 2 marca 1980 i 29 czerwca 1985.

37 Żaba do Rudzkiego (2 marca 1980), AAN. Kopię tego listu Żaba wysłał do Giedroycia.

${ }^{38}$ Ibidem.

${ }^{39}$ Giedroyc do Żaby (8 i 11 listopada 1982), AIL. Analogicznie przedstawiał się stosunek Giedroycia do „Zeszytów Literackich” redagowanych przez Barbarę Toruńczyk. Zob. M. Grochowska (2009), Jerzy Giedroyc. Do Polski ze snu, Warszawa: Świat Książki, s. 375-377. 


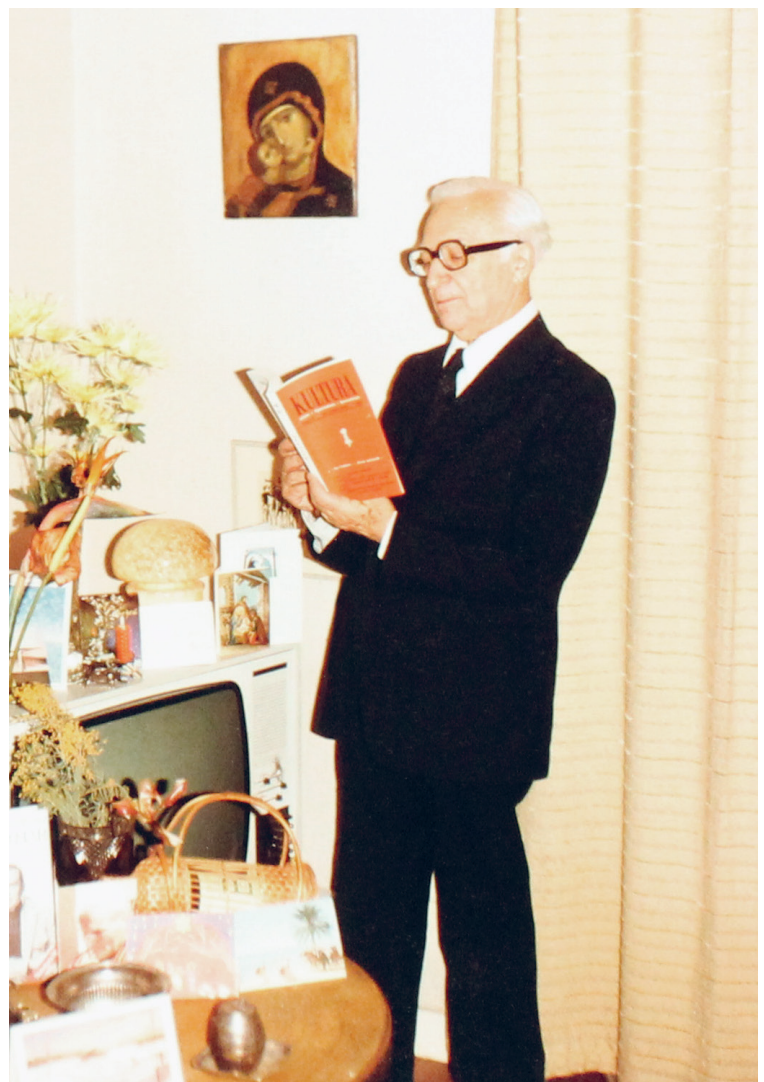

2. Norbert Żaba we własnym mieszkaniu, Sztokholm, data i autor nieznane, akta Norberta Żaby w Archiwum Akt Nowych w Warszawie.

jak interesy partykularne kruszyły jedność w obozie emigrantów. Listy prywatne często w historii stanowiły narzędzie ostrej krytyki ${ }^{40}$. Giedroyc nie powtarzał tych opinii publicznie. Mimo animozji środowisko wydawców łączyła nadal milcząca solidarność związana z wykonywaniem tego samego zdania, chęcią pomocy Polsce. Żaba nie podzielał w sprawie "Aneksu” opinii Giedroycia, choć mu uległ. Zbyt wiele łączyło go z „Kulturą," by z nią zerwać z takiego powodu. Animozje $\mathrm{z}$ „Aneksem” można rozpatrywać w szerszym kontekście jako reakcje emigrantów na zagrożenie ze strony własnego otoczenia. Konflikty wewnętrzne występują właściwie we wszystkich diasporach - przekonuje Sabine Freitag, badaczka uchodźctwa politycznego z kontynentalnej Europy w XIX-wiecznym Londynie, która bardzo

${ }^{40}$ M. Kula (2010), Najszczersze ze szczerych? Refleksje o wartości źródłowej tekstów prywatnych (na przykładzie własnych listów o własnej szkole), w: Kolbuszewska J., Stobiecki R. (red.), Historyk wobec źródet: historiografia klasyczna i nowe podejścia metodologiczne, Łódź: Polskie Towarzystwo Historyczne, s. 185-206. 
ciekawie opisuje, jak grupa politycznych uchodźców z Niemiec pokłóciła się o pieniądze, zanim jeszcze je zebrała w publicznej zbiórce. Rozdźwięki personalne na wygnaniu wzmagały na sile ze względu na ograniczone możliwości politycznej aktywności z jednej strony i nadmiar inteligencji w szeregach diaspory z drugiej. W takiej wspólnocie wszyscy chcą odgrywać pierwszoplanowe role. „Zbyt wielu wodzów, zbyt mało Indian" - uważa niemiecka badaczka ${ }^{41}$.

\section{Wobec diaspory w Szwecji}

Z biegiem lat i z dala od kraju Żaba prezentował stanowisko krytyczne wobec polskiego egocentryzmu: „Młode pokolenie jest przeczulone na punkcie patriotyzmu i narodowości polskiej. Nie toleruje najmniejszej krytyki polskości” - pisał do Giedroycia ${ }^{42}$. Dobre słowa pod adresem „Kultury” jako „pisma o szerokim liberalno-demokratycznym obliczu” świadczyły wymownie, że Żaba wyzbył się też młodzieńczego autorytaryzmu ${ }^{43}$. Pozostawał jednak w pewnych sprawach konserwatywny „pamiętaj, byłem przez całe życie umiarkowanym prawicowcem czy konserwatystą, nigdy nie wykazywałem odchyleń nacjonalistycznych (Narodowa Demokracja, Obóz Narodowo-Radykalny) ani lewicowych (socjalizm, komunizm)” - pisał w 1986 roku do redaktora paryskiej „Kultury” 44 . Można by go określić mianem „rozsądna” prawica, wroga nacjonalizmowi, o szerokich horyzontach. Żaba lubił podkreślać swoją wierność zasadom. Ludzi, którzy mieli w swoim życiu ostre zwroty ideowe, łatwo podejrzewał o oportunizm. Stąd brała się u niego pewna rezerwa wobec emigracji marcowej - w szczególności wobec dawnych działaczy $\mathrm{PZPR}^{45}$. Zarazem potrafił jednak docenić ewolucję ich postaw życiowych ${ }^{46}$.

O tolerancyjnym nastawieniu Żaby świadczyło prowadzone przez niego Towarzystwo Przyjaciół „Kultury”. Klub ten oficjalnie powstał 14 maja 1971 roku. Żaba zainicjował spotkanie z działaczami studenckimi Marca'68. Poruszono na nim problem polskiego antysemityzmu ${ }^{47}$. W następnych latach do tłumnie obleganych prelegentów należeli Adam Michnik, Leszek Kołakowski i Stefan Kisielewski (druga połowa lat 70. XXw.). Na spotkania z nimi przychodziło nawet 150-200 osób. Sala

${ }^{41}$ S. Freitag (2003), “The Begging Bowl of Revolution”: the Fund-raising Tours of German and Hungarian Exiles to North America, 1851-1852, w: Freitag S. (red.), Exiles from the European Revolution: Refugees in mid-Victorian England, New York: Berghahn Books, s. 164-186.

42 Żaba do Giedroycia (29 sierpnia 1985), AIL.

43 Żaba do Giedroycia (19 listopada 1988), AIL.

${ }^{44}$ Żaba do Giedroycia (11 lipca 1986), AIL.

45 Żaba do Rudzkiego (26 marca 1974), AAN.

${ }^{46}$ Więcej na temat mozaiki środowisk emigracyjnych w Szwecji w: A. Kłonczyński (2012), My w Szwecji nie porastamy mchem... Emigranci z Polski w Szwecji w latach 1945-1980, Gdańsk: Wydawnictwo Uniwersytetu Gdańskiego, s. 99-195.

${ }^{47}$ J. Korek, Norbert..., s. 48. 
pękała w szwach. Podobnie było w 1980 roku na spotkaniu z Czesławem Miłoszem po przyznaniu mu literackiej nagrody Nobla, czy na wieczorze ze Zdzisławem Najderem (1982). Dwa razy w Sztokholmie pojawił się wieloletni szef polskiej sekcji Radia Wolna Europa Jan Nowak Jeziorański i zawsze przyciągał tłumy. W 1987 roku zawitali do Sztokholmu Jacek Kuroń i Janusz Onyszkiewicz ${ }^{48}$. Imprezy były biletowane, by pokryć koszty wynajmu lokalu, choć niektórzy wchodzili po kryjomu tylnymi drzwiami. Żaba po odczycie i dyskusji organizował bufet i fundował wino. Czasami towarzystwo przenosiło się na dalsze nocne dyskusje do niego do domu.

Mimo rosnącego poważania wśród rodaków, Żaba popadał w coraz większe zgorzknienie ze względu na endemiczną konfliktowość środowisk emigracyjnych. W listach do Giedroycia opisywał z niesmakiem życie wewnętrzne sztokholmskiej emigracji, walki frakcji, bufonadę kanapowych prezesów ${ }^{49}$. Zawiódł się na młodych, którym wcześniej pomagał w stawianiu pierwszych kroków w Szwecji. Szczególną niechęć żywił do redaktora sztokholmskiej „Jedności” Ludomira Gąssowskiego-Garczyńskiego, który - jak twierdził - zwalczał go i opluwał, mimo że początkowo Żaba cenił go i mu pomagał ${ }^{50}$. Pretensje Żaba formułował w konwencji: winni są inni, on zawsze jest ofiarą. W latach 80 . XX wieku mnożyły się zawiści i intrygi - te prawdziwe i jedynie urojone, jak na przykład, fałszywe podejrzenia Żaby wobec Gąssowskiego o tajną współpracę $\mathrm{z}$ ambasadą PRL-u ${ }^{51}$. Giedroyc i Żaba bronili swoich wpływów, jakby nie rozumiejąc, że młodzi z czasem próbują się usamodzielnić i może to odbywać się w zderzeniu ze starymi ${ }^{52}$.

Na stosunku starych do młodych ważyła nie tylko polityka, ale również odmienne wzory kulturowe, style zachowania i obyczaje. Choć Towarzystwo Przyjaciół „Kultury” prowadzone przez Żabę działało jako pomost do nowej emigracji, to jednak jego inicjator nie mógł się powstrzymać od krytykowania długowłosych, brodaczy, niechlujnie ubranych (podarte dżinsy): „wyglądają jak Papuasi” - pisał do Giedroycia ${ }^{53}$. By zdobyć u Żaby poważanie, należało ubierać się formalnie,

48 Żaba składał relacje Giedroyciowi z zebrań Towarzystwa; zob. listy z 20 kwietnia 1977, 13 sierpnia 1978, 8 listopada 1980, 9 marca 1983. Relacja ze spotkania z Kuroniem i Onyszkiewiczem bez daty (po strajkach majowych 1988, być może lipiec 1988), AIL.

49 Żaba do Giedroycia (12 sierpnia 1971, 17 września 1975), AIL.

50 Żaba do Rudzkiego (30 stycznia i 16 czerwca 1978), AAN; Żaba do Giedroycia (31 grudnia 1976, 31 sierpnia 1984), AIL. Por. L. Garczyński-Gąssowski (2014), Wydawnictwa i rozdawnictwa, w: Flis S. (red.), Emigracja a środowiska niezależne w kraju, Gdańsk-Bydgoszcz: Instytut Pamięci Narodowej, s. 64-65; L. Garczyński-Gąssowski (1994), Norbert Żaba, „Gazeta Wyborcza” [„Gazeta Stołeczna”], nr 240, s. 12. Gąssowski nie odnosił się do zadrażnień z Żabą i - przynajmniej po latach pozytywnie przedstawiał postać Żaby. Napisał o nim również pośmiertne wspomnienie.

${ }_{51}$ Żaba do Giedroycia (7 i 19 listopada 1988), AIL. Wydaję się, że Żaba mylił się w sprawie Gąssowskiego. Nie znalazłem żadnych śladów w archiwum IPN, które uwiarygodniałyby jego podejrzenia.

${ }^{52}$ Świadczą o tym wzmiankowane wcześniej listy na temat „Aneksu”. Więcej na ten temat w: M. Grochowska, Jerzy..., s. 375-377.

53 Żaba do Giedroycia (30 maja 1970 oraz 7 września 1971), AIL. 
w garnitur i krawat. Dla Żaby - wyrosłego w klimacie Polski przedwojennej normalność oznaczała konwencje tamtej epoki. Hippisów w jednym z listów uznał za kulturowych agentów lewicy ${ }^{54}$. Na podstawie takich wyobrażeń krytykował nieraz młodych emigrantów za brak kindersztuby, odpowiedniego wychowania, dobrych manier ${ }^{55}$.

\section{Na północnym szlaku książki}

Wzrost znaczenia szlaku skandynawskiego datuje się od początku lat 70. XX wieku, kiedy to Szwecja zniosła wizy dla Polaków i otworzyła częściowo rynek pracy sezonowej dla studentów z Polski. Częściej niż wcześniej kursował prom z Gdyni do Sztokholmu oraz ze Świnoujścia do Ystad ${ }^{56}$. U progu dekady Żaba nie dostrzegał jeszcze koniunktury. Giedroyc jednak bezbłędnie wyczuwał nowe możliwości i to on w 1972 roku namówił Żabę do większej aktywności kolporterskiej i podjęcia bezpośredniej współpracy z nowojorskim ILC ${ }^{57}$. Pośrednicy na tak długim szlaku są niezbędni, tak zresztą jak i pewna infrastruktura, bez której transfer byłby niemożliwy - poczta, statki, samochody, punkty kolportażowe.

Przeciętny czytelnik z Polski często odczuwał niepokój przed zaangażowaniem się w przemyt nawet drobnych porcji literatury. Wizja dobrych zarobków w Szwecji odciągała zdecydowaną większość młodzieży od punktu kolportażu Żaby. Zbieracze truskawek czy zatrudnieni jako pomoc fizyczna w barach i restauracjach mieli wiele do stracenia w wypadku przeszukania na granicy, niektórzy bali się przesadnie sprawności służb celnych. Żaba starał się jednak umiejętnie przyciągać do siebie przybyszów domową atmosferą, przyjazną rozmową, dyskrecją. Według niego, decydowały tu często rzeczy drobne, jak postawienie drinka, ugoszczenie obiadem $^{58}$. Przybysze z Polski niepewnie poruszali się na obcym im gruncie. Żaba mógł im niejedno doradzić, wystąpić w roli tłumacza, wskazać, gdzie można korzystnie sprzedać przemycone z Polski złoto, diamenty, kiełbasę i wódkę, gdzie szukać noclegu, jak najkorzystniej wymienić korony na dolary.

Nie po raz pierwszy w historii przemyt miał cechy działania systemowego, angażującego sporo ludzi ${ }^{59}$. Żaba zbierał informacje o systemie kontroli granicznej w polskich portach - przepisach, wpadkach, zwyczajach celników. Pracownicy urzędów celnych chętnie przyjmowali drobne prezenty od podróżujących. Te łapówki okazywały się bodajże najlepszą bronią przemytników. „Dla ułatwienia bezbolesnego przewozu książek radzę klientom swoim dawać celnikom po dwie

${ }^{54}$ Żaba do Giedroycia (5 lutego 1972), AIL.

55 Żaba do Giedroycia (2 stycznia 1983, 14 czerwca 1986), AIL.

${ }^{56}$ A. Kłonczyński, $M y \ldots$..., s. 39.

${ }^{57}$ Giedroyc do Żaby (13 lutego i 16 marca 1972), AIL.

${ }^{58}$ Żaba do Zofii Hertz (3 września 1974), AIL, Żaba do Rudzkiego (23 października 1978), AAN.

59 Ch. McCooey (2012), Smuggling on the South Coast, Chalford: Amberley Publishing. 
paczki papierosów” - pisał do Adama Rudzkiego z nowojorskiego ILC ${ }^{60}$. W drugiej połowie lat 70. XX wieku testowano różne triki przemytnicze, na przykład wkładanie książek pod pasek spodni i nakładanie marynarki, jako że kontrole osobiste zdarzały się rzadziej niż bagażu. Ta metoda, dość szybko porzucona, została pod koniec lat 70. XX wieku zastąpiona przez tak zwane miniaturki - książki w formacie kieszonkowym, które można było łatwo schować w odzieży ${ }^{61}$. Turyści dość chętnie godzili się na małe książki, mimo niedużego druku oraz wyraźnie przemytniczego wyglądu, co mogło przysporzyć kłopotów w razie wykrycia kontrabandy ${ }^{62}$.

Żaba rozdawał parę sztuk na osobę, by nie narażać swoich współpracowników na kłopoty, ale również by docierać do możliwie wielu rejonów i środowisk. Wwożący prohibita byli proszeni o przesłanie Żabie kartki pocztowej po powrocie do kraju z hasłem - pogoda dobra, przyjemna podróż. W razie niepowodzenia pisało się o chorobie morskiej ${ }^{63}$. Żaba starał się skupić wokół siebie grupę stałych odbiorców, tworzyć przemytniczą wspólnotę. Stwarzało to większe szanse na śledzenie losów literatury przemyconej. Przy kolejnym spotkaniu można było szczegółowo wypytać o nastroje w kraju, reakcje czytelników, sposoby rozchodzenia się publikacji. Wiedza ta pozwalała na określenie, które tytuły cieszą się większym powodzeniem, w jaki sposób należy pokierować przemytem do Polski, które środowiska odczuwały brak literatury. Zasłyszanymi informacjami Żaba skrupulatnie dzielił się z Jerzym Giedroyciem i amerykańskim patronami z Nowego Jorku. Ci ostatni odwzajemniali się wiadomościami. Taka wymiana zwiększała skuteczność działań.

Zazwyczaj Żaba nie podawał nikomu nazwisk zaufanych i najbardziej skutecznych kurierów ${ }^{64}$. W 1985 roku ujawnił jednak Amerykanom swojego dobrego przewoźnika - Elżbietę Nowicką z Krakowa, germanistkę, wykładowczynię języka szwedzkiego na Uniwersytecie Jagiellońskim ${ }^{65}$. Poznał ją w 1978 roku, później brała od niego książki również w 1979 i 1981 roku i przewoziła „pod szeroką spódnicą ${ }^{66 ”}$. W 1985 roku Nowickiej udało się wwieźć 57 kilogramów literatury zakazanej, co było rekordem jednorazowego przerzutu indywidualnego. Na możliwości Nowickiej - poza wielką determinacją - wpływały je dobre kontakty w świecie szwedzkim. Zaradna przemytniczka poszła do fabryki proszków do prania w Szwecji i przedstawiła się jako organizatorka przerzutu książek do Polski. W fabryce dostała oryginalne opakowania i zamknięcia, dzięki którym mogła zapakować książki

${ }^{60}$ Żaba do Rudzkiego (21 września 1980), AAN.

${ }^{61}$ Więcej na ten temat w: P. Sowiński, Tajna..., s. 36, 44, 49, 57, 145.

${ }^{62}$ Miniaturki miały format nie większy niż $11 \mathrm{~cm}$ długości i $7 \mathrm{~cm}$ szerokości. Z jednej strony łatwiej było je schować, z drugiej - wyglądały jak wyprodukowane specjalnie do celów przemytniczych. Posiadacze miniatur obawiali się, że zostaną potraktowani przez służby celne jako przemycający z premedytacją zakazane treści do kraju.

${ }_{63}$ Żaba do Rudzkiego (październik 1978, 1 lipca 1980), AAN.

${ }^{64}$ Żaba do Rudzkiego (30 maja 1973), AAN.

${ }_{65}$ Żaba do Rudzkiego (2 września 1985), AAN.

${ }^{66}$ Ibidem. 
w sposób niebudzący podejrzeń. Nie wiemy, czy miała samochód, ale z pewnością dowiozła cały transport do Krakowa. Nowicka zaopatrywała krąg uniwersytecki oraz robotników z Nowej Huty, którzy mieli kontakt z grupą uniwersytecką ${ }^{67}$.

W latach 70. XX wieku Żaba rozdawał kilkaset książek miesięcznie, w okresie letnim. W kwietniu i maju 1974 Żaba wydał 182 egzemplarze $^{68}$, tym samym dwumiesięcznym okresie roku 1978 - już $502^{69}$, a w 1980 roku w porównywalnym czasie $-778^{70}$. Lipiec i sierpień przynosiły wzrost co najmniej dwukrotny. W czerwcu 1981 Żaba wydał po raz pierwszy więcej niż 1000 egz. (w okresie miesięcznym) ${ }^{71}$. Po krótkim okresie pogorszenia koniunktury w wyniku stanu wojennego Żaba pobijał kolejne rekordy. W maju 1984 Żaba wydał już ponad 2100 wydawnictw do Polski ${ }^{72}$. W dobrych miesiącach przychodziło na ulicę Kallskärsgatan średnio 3-5 osób dziennie. Liczby mówią jedynie o książkach wydanych gościom z kraju. Pewna część gratisów po przeczytaniu trafiła do kosza jeszcze w Szwecji, inne czytelnicy wyrzucali do morza przed przypłynięciem promu do polskich portów. Oddalenie od kraju uruchamiało w mieszkańcach PRL-u potrzebę wolności; pragnienie to jednak słabło, gdy znów zbliżali się do granicy ${ }^{73}$.

\section{Praktyki czytelnicze}

Większość wydawnictw przemyconych - nie tylko od Żaby - trafiała do sfer uniwersyteckich, naukowych, studenckich. Odwagę mieli częściej studenci. Jedni brali rzeczy mniej polityczne (np. dzieła literackie), by zmniejszyć własne ryzyko, inni wydawnictwa najbardziej potępiane przez władze (np. publicystyka polityczna emigracji). Chyba dla większości podróżnych prohibity stanowiły odmianę i ucieczkę od komunistycznej rzeczywistości. W kraju egzemplarze były zaczytywane, do książek tworzyły się długie kolejki - pisał w listach Żaba. Od 1977 roku opozycja w kraju zakładała biblioteki niezależne, m.in. Studencki Komitet Solidarności w Krakowie, którego zbiory Żaba zasilał ${ }^{74}$. Najszerszy krąg, choć nie bez pewnych trudności, nadal korzystał z publikacji w oficjalnych bibliotekach, które miały zezwolenie na gromadzenie książek emigracyjnych w tak zwanych zbiorach zastrzeżonych.

Wysyłka do bibliotek wymagała jednak pomysłowości. Od 1976 roku Żaba trafił na listę osób niepożądanych w PRL- $\mathrm{u}^{75}$. Można było podejrzewać, że jego

${ }^{67}$ Ibidem.

${ }_{68}$ Żaba do Rudzkiego (24 września 1974), AAN.

69 Żaba do Rudzkiego (16 czerwca 1978), AAN.

70 Żaba do Giedroycia (3 lipca 1980), AIL.

${ }^{71}$ Żaba do Giedroycia (28 października 1981), AIL.

${ }_{72}$ Żaba do Giedroycia i Zofii Hertz [b.d., koniec 1984 roku], AIL.

${ }_{73}^{73}$ M. Kula, Fale..., s. 71.

${ }_{74}$ Żaba do Rudzkiego (16 czerwca 1978), AAN.

${ }^{75}$ Notatka dot. kolportażu antypolskich publikacji na terenie Szwecji, AIPN, 1268/30633, s. 19-20. 
sztokholmski adres nie nadawał się do nadawania paczek z książkami do Polski. Pośredniczyła w tej spedycji - przynajmniej od 1977 roku - Katarzyna Gruber, z pomarcowej emigracji, bibliotekarka w Bibliotece Szwedzkiej Akademii Noblowskiej $^{76}$. Książki dostawały szwedzki stempel Biblioteki, choć nigdy tam nie trafiały. Od Gruberowej Żaba dostawał oficjalne nalepki „noblowskie” na koperty i sam wysyłał na poczcie. W ten sposób jego kolportaż zdobył szturmem miejsce na półkach Biblioteki Narodowej, Instytutu Badań Literackich PAN oraz Jagiellonki. Sytuacja tych bibliotek jednak była odmienna. Najwięcej konfiskat zdarzało się w IBL-u, szczególnie w latach 80. XX wieku za czasów proreżimowego dyrektora Witolda Nawrockiego. Zespół Gruberowa-Żaba największe sukcesy odnosił w Jagiellonce, gdzie dyrekcja, i sam rektor Uniwersytetu, po cichu akceptowali ten przerzut ${ }^{77}$.

Przyjezdni z Polski opowiadali Żabie niezwykłe historie związane z odbiorem treści zakazanych. Pewien młody mężczyzna zwierzył się, że właśnie publikacje emigracyjne wzbudziły w nim niezadowolenie z sytuacji w kraju, namówił do lektury również swoją 21-letnią dziewczynę. Ta - podobno pod wpływem publikacji „Kultury” - zerwała z rodzicami, głównie z ojcem, pułkownikiem Wojskowej Akademii Technicznej w Warszawie ${ }^{78}$. Czytanie zainspirowało ich do opuszczenia Polski na stałe. Inni poprzestawali raczej na wykradaniu publikacji z domowych bibliotek prominentnych rodziców. W tym kontekście Żaba wymienił syna Stanisława Wrońskiego, od 1972 roku prezesa ZBoWiD-u. Ze zbiorów „Kultury” u starego Wrońskiego po kryjomu korzystali również inni koledzy, w tym Henryk Skwarczyński, syn Zdzisława, rektora Uniwersytetu Łódzkiego w latach 1968-1972 ${ }^{79}$. Nie wszyscy doczekali się książki, jak młody lekarz nieznany z imienia Szymasiuk, który był dalekim numerem na liście oczekujących na Sołżenicyna; nie zdążył przeczytać przed wyjazdem do Szwecji ${ }^{80}$.

Refleksje Żaby dostarczają więcej materiału źródłowego, cennego w kontekście rozważań nad oddziaływaniem nowych idei na umysły ludzi. Lektury książek bez cenzury zapewne promowały bardziej demokratyczne wzory zachowań, ale jest to sprawa bardzo skomplikowana. Mediom opozycyjnym wobec PRL-u badacze przypisują teraz dość chętnie znaczenie w niszczeniu mitów, symboli i rytuałów komunistycznych. Wyrywkowość i niejednoznaczność przekazów historycznych na temat oddziaływania publikacji na umysły ludzi nie pozwala na wyprowadzenie rozległego dowodu na mentalną transformację polskiej inteligencji - co najwyżej

${ }^{76}$ Krótkie hasło biograficzne Katarzyny Gruberowej: T. Nowakowski (2013), Leksykon emigracji polskiej w Szwecji. Do 2012 roku, Nowakowski T. (red.), Sztokholm: Wydawnictwo Polonica, s. 70.

77 Żaba do Rudzkiego (27 czerwca 1986 i 12 marca 1987), AAN. Rektor - pisał Żaba w 1987 roku - jako poseł z ramienia Stronnictwa Demokratycznego miał pewną pozycję w systemie władzy i mógł pozwolić sobie na większą niezależność.

78 Żaba do Rudzkiego (9 lutego 1977), AAN.

79 Żaba do Rudzkiego [b.d., około 1977 roku], AAN.

${ }^{80}$ Żaba do Rudzkiego (16 września 1974), AAN. 
można prześledzić stan świadomości jednostek, ale już nie całego kręgu czytelników drugiego obiegu. Ruch wydawnictw niezależnych nie znalazł się wówczas pod obserwacją ośrodków badania opinii społecznej, a tylko te mogłyby dostarczyć danych bardziej zagregowanych i systematycznie zbieranych ${ }^{81}$. Odpowiedź na pytanie o wkład książkowej dywersji w erozję systemu władzy jest więc bardzo trudna.

\section{Sojusznicy}

Szwedzki badacz Lars Fredrik Stöcker wprowadza do powyższych rozważań niezbędny kontekst zewnętrzny. W ujęciu Stöckera transfer książek przez Bałtyk - jego rozmiar i kształt - jest wynikiem wielu interakcji transnarodowych. Paradygmat narodowy nie wystarcza więc również do opisania historii Żaby. O ile początki jego kolportażu w Jugosławii można tłumaczyć związkami z kręgiem paryskiej „Kultury”, o tyle późniejsza aktywność powinna być wyjaśniana nie tylko poprzez układ sił wewnątrz wspólnoty polskiej. Krążenie idei między Wschodem a Zachodem trzeba postrzegać jako zjawisko paneuropejskie - twierdzi Stöcker ${ }^{82}$. Coraz większe możliwości kolportażu Żaby zbiegły się z ociepleniem stosunków międzynarodowych w latach 70. XX w. Polska uważała Szwecję za politycznie bezpieczną, nieskorą do prowadzenia ostrej zimnowojennej kampanii przeciwko komunizmowi, ani żadnych akcji, które naruszałyby jej neutralność, wprowadzałyby do polityki międzynarodowej element konfrontacji ${ }^{83}$.

Efekt detente przyczynił się do ożywienia kontaktów na wszystkich poziomach, także tych niechcianych przez stronę komunistyczną i przyspieszył rozwój opozycji. Rząd szwedzki widział pewien dylemat w aktywności polskiej emigracji politycznej, częściowo wrogiej PRL-owi. Liczył się z tym, że jej obecność raczej szkodzi niż pomaga interesom Szwecji w Polsce. Biuro Radia Wolna Europa w Sztokholmie - zdaniem Stöckera - drażniło Szwedów najbardziej, ale nie bez znaczenia było pojawienie się w Szwecji emigrantów fali Marca '68, w przeważającej części inteligentów, co dodało diasporze żywotności, rozwijało również kolportaż Żaby ${ }^{84}$. Szwedzkie władze nie zamierzały ingerować w pracę na rzecz poszerzenia sfery wolności w Polsce. Byłoby to sprzeczne ze szwedzkim prawodawstwem dotyczącym

${ }^{81}$ Pewne próby zmierzenia się z tym problemem podjęto zarówno teraz, jak i jeszcze w podziemiu. Więcej na temat szacunków statystycznych społecznego oddziaływania w: P. Sowiński (2011), Zakazana książka. Uczestnicy drugiego obiegu 1977-1989, Warszawa: Instytut Studiów Politycznych, s. 258.

${ }^{82}$ L.F. Stöcker (2012), The Baltic Connection. Transnational Samizdat Networks between Émigrés in Sweden and the Democratic Opposition in Poland, w: Kind-Kovács F., Labov J. (red.), Samizdat, Tamizdat and Beyond. Transnational Media during and after Socialism, New York-London: Berghahn Books, s. 61.

${ }^{83}$ Ibidem, s. 54.

${ }^{84}$ Ibidem, s. 55. 
uchodźców politycznych i liberalnymi tradycjami politycznymi. Nie bez znaczenia okazała się pomoc szwedzka dla opozycji w Polsce - zarówno dotacje, zbiórki, jak i zaangażowanie szwedzkich obywateli w przemyt do Polski ${ }^{85}$.

Literatura nazywa taką kooperację mianem międzynarodowej sieci wsparcia (transnational advocacy network). Dzięki niej wybory moralne polskiej opozycji zyskiwały wymiar międzynarodowy, stawały się częścią uniwersalnego pakietu wartości i symboli ${ }^{86}$. Tymczasem od 1956 roku wydawcy emigracyjni z Europy Środkowo-Wschodniej zyskiwali silnego partnera instytucjonalnego - rządowy amerykański program książkowy. Ten czynnik jest nieobecny w rozważaniach Stöckera. W latach 70 . XX wieku program ten w dużym stopniu regulował ruch książki na szlaku bałtyckim. Wspomniana już nowojorska ILC za pieniądze rządu USA dynamizowała emigracyjny ruch wydawniczy, wspierała kolportaż darmowej literatury. Zasady wzajemnej zależności, choć były już omawiane, nie zostały $\mathrm{w}$ dotychczasowej literaturze dobrze rozpoznane ${ }^{87}$. Żaba znalazł się pod patronatem amerykańskim w 1972 roku, kiedy nawiązał bezpośrednie kontakty z Adamem Rudzkim, pracownikiem ILC do spraw polskich.

Nasuwa się pytanie o naturę tej polsko-amerykańskiej relacji. Czy Żaba został zdominowany przez politykę amerykańską? Czy była to kooperacja, czy też może raczej kooptacja Żaby do programu książkowego? Za tą drugą hipotezą przemawia fakt, że ILC było strukturą hierarchiczną z centralą w Nowym Jorku i terenowymi przedstawicielami w Europie Zachodniej. Emigranci zależeli od centrali w sprawach finansowych i organizacyjnych. Przykład Norberta Żaby pokazuje zarazem dużą autonomię działania pośredników na drodze książki emigracyjnej do Polski. Wspólne cele polityczne wskazywały na partnerstwo obu stron. Każda z nich wyciągała korzyści z tej współpracy. Amerykanie pomogli emigrantom zaktywizować się politycznie, z kolei emigranci zgodzili się odegrać pewną rolę $\mathrm{w}$ amerykańskim scenariuszu wojny informacyjnej z blokiem państw znajdujących się pod radziecką dominacją.

W latach 70. i 80. XX w. Żaba otrzymywał z ILC około 300 dolarów miesięcznie za kolportaż wydawnictw i sporządzanie sprawozdań ${ }^{88}$. W listach do Rudzkiego wskazywał na swoje atuty - unikalne możliwości działania w Szwecji poparte znajomością języków, lokalnych warunków, środowiska polskiego i szwedzkiego. Przekonany o swojej pozycji dość twardo negocjował z Nowym Jorkiem warunki pracy.

${ }^{85}$ Tezy Stöckera potwierdza Żaba w swoich listach: Żaba do Rudzkiego (październik 1978, 3 sierpnia 1979), AAN; Żaba do Giedroycia (20 maja 1970, 7 września 1971, 22 sierpnia 1976), AIL.

${ }^{86}$ R. Brier (2013), Introduction, w: Brier R. (red.), Entangled Protest: Transnational Approaches to the History of Dissent in Eastern Europe and the Soviet Union, Osnabrück: Fibre; M. Keck i K. Sikkink, Activists beyond Borders... s. 1-2.

${ }^{87}$ Najwięcej na ten temat pisał A.A. Reisch w cytowanej książce Hot Books in the Cold War.

${ }^{88}$ Od 1976 roku - 300 dolarów, od 1978 - 350 dolarów za dystrybucję polską i rosyjską. List do Rudzkiego (23 października 1978), AAN; List George’a Mindena do Norberta Żaby (17 kwietnia 1989), AAN. 
Odrzucał płynące zza oceanu sugestie, by podawać nazwiska odbiorców książek i kurierów. Niezbyt chętnie wypełniał wymogi pracy papierkowej, nakładanej na wszystkich dystrybutorów przez system książkowy. Walczył - niekiedy z sukcesami - o podwyższenie limitów wydawnictw przeznaczonych do darmowego kolportażu. Utyskiwał na niewielkie honoraria, grożąc czasami zerwaniem współpracy z Amerykanami, do czego jednak nigdy nie doszło. Zdawał sobie bowiem sprawę, że bez pomocy USA jego praca na rzecz Polski znacznie by się zmniejszyła ${ }^{89}$.

Ostatecznie nawet zadziorny Żaba rozumiał, że w potyczkach z Rudzkim lepiej wygrać częściowo niż stracić wszystko. W 1976 roku Żaba objął w Sztokholmie radziecki kierunek operacji - najtrudniejszy ze względu na despotyzm i przemoc władz komunistycznych ${ }^{90}$. Teoretycznie otwierały się przed nim wielkie obszary penetracji, ale Żaba miał zbyt mało chętnych do przemycania książek do ZSRR. Kolportował ledwie kilkadziesiąt wydawnictw rosyjskich miesięcznie, czasami mniej ${ }^{91}$. Tymczasem w latach 70. i 80. XX wieku kierunek rosyjski stawał się dla USA najbardziej priorytetowy ${ }^{92}$. Żaba musiał przyjąć do wiadomości, że jego pozycja przetargowa zależy od wyników w dystrybucji rosyjskiej. Kontakty, które jednak nawiązał z Rosjanami, Estończykami, Łotyszami stawiały go w rzędzie dystrybutorów międzynarodowych.

\section{Oponenci}

W realiach Polski Ludowej emigracją polityczną zajmowała się wyspecjalizowana jednostka wywiadu PRL-u - wydział XI i jego wcześniejsze wcielenia. Komórki wywiadu za granicą rutynowo inwigilowały ważniejsze osobistości i organizacje diaspory. Oficjalnie nazywano je w PRL-u - „ośrodkami dywersji ideologicznej”. W tym kontekście postawa władz komunistycznych wobec Żaby to kolejny przykład długoletniej akcji zwalczania emigracji politycznej ${ }^{93}$. Pierwszym sygnałem była kontrola korespondencji i inwigilacja matki Żaby - Klary, mieszkającej w Polsce - prowadzona od 1954 roku przez Ministerstwo Bezpieczeństwa Publicznego ${ }^{94}$. Wkrótce wywiad PRL-u przeszedł do działań ofensywnych z udziałem agentury

89 Żaba do Giedroycia (23 września 1973), AIL; Żaba do Rudzkiego (30 maja 1973, 21 października 1976, 12 września 1986), AAN; Żaba do Giedroycia (9 kwietnia 1973), AIL.

${ }^{90}$ Rudzki do Żaby (27 stycznia 1976), AAN. Na temat przemytu do ZSRR zob. również: L.F. Stöcker (2014), Nylon Stockings and Samizdat. The "White Ship" between Helsinki and Tallin in the Light of its Unintended Economics and Political Consequences, "Zeitschrift für Ostmitteleuropa-Forschung", no 63 , s. 374-398.

${ }_{91}$ Żaba do ILC (3 sierpnia 1978), AAN; Żaba do Giedroycia (19 sierpnia 1977), AIL.

${ }_{92}$ Rudzki do Żaby (12 marca 1981), AAN.

${ }^{93}$ K. Tarka (2014), Jest tylko jedna Polska? Emigranci w stużbie PRL, Łomianki: Wydawnictwo LTW, s. 5-17.

${ }^{94}$ Więcej w: A. Kłonczyński, My..., s. 246-247. 
w Szwecji. Miały one na celu dezintegrację środowiska emigrantów politycznych, określanej jako grupa pułkownika Witolda Szymaniaka ${ }^{95}$. Z racji swojej pracy dla przedwojennego II Oddziału Sztabu Generalnego Wojska Polskiego Szymaniak doradzał Żabie w sprawach wywiadowczych.

Żaba w 1977 roku dyskretnie zdemaskował agentów wywiadu PRL-u: dziennikarza Leszka Szopę i marynarza Bogusława Andrzejewskiego ze Szczecina, na długo zanim tego odkrycia dokonał IPN ${ }^{96}$. Żaba nie miał złudzeń co do pracy służb specjalnych na terenie Szwecji i zalecał wszystkim innym emigrantom wielką ostrożność w rozgłaszaniu własnej pracy dla Polski. Misja Szopy i Andrzejewskiego to dowód na to, że rosnąca rola Żaby nie uszła uwadze służb specjalnych. Od drugiej połowy lat 70. XX wieku władze PRL-u próbowały odzyskać kontrolę na bałtyckim szlaku komunikacyjnym. W rozgrywce z wywiadem pomogło Żabie jego długoletnie doświadczenie polityczne. „Coś mi tu nie gra” - ostrzegał w 1977 roku Giedroycia przed Leszkiem Szopą, który przybył do Szwecji rzekomo jako tajny wysłannik Komitetu Obrony Robotników. Faktycznie jednak miał za zadanie opanować, a następnie przerwać kanał przerzutowy Polska-Szwecja. „Metody pracy są dzisiaj inne, subtelniejsze - ciągnął Żaba - Służba Bezpieczeństwa pracuje przez dywersje, infiltracje, prowokacje, oszczerstwa" ${ }^{\prime 97}$.

W latach 80. XX wieku Żaba pisał o pracy instancji wywiadowczych głównie w kontekście różnych „wtyczek”, które przeniknęły do Szwecji jako emigranci polityczni. Dowodów na jego przypuszczenia na ogół nie udało się odnaleźć w aktach IPN. Kto wie jednak czy nie bardziej skuteczna była zupełnie jawna, a nawet szeroko reklamowana, polityka neutralizowania emigracji. W dekadzie rządów Jaruzelskiego ambasada PRL-u organizowała przyjęcia dla emigrantów, starając się pozyskać ich względy czy po prostu kupić ich drobnymi przywilejami. Rząd polski miał pewne możliwości, ponieważ wielu uchodźcom - związanym więzami rodzinnymi z krajem - zależało na podróżach do ojczyzny. „W ostatnim czasie miało się odbyć w ambasadzie przyjęcie dla środowiska lekarzy i dentystów polskich (kanapki i alkohol). Podobno było tłumnie" - utyskiwał nieprzekupny Żaba ${ }^{98}$. Do ambasady udali się nawet niektórzy prenumeratorzy „Kultury”. Żaba ze smutkiem zakładał, że na raut poszła także jego dentystka, jako że jeździła ona do kraju ${ }^{99}$.

95 T. Nowakowski, Leksykon..., s. 243.

96 P. Szulc (2007), Zabawa w szpiega, „Biuletyn Instytutu Pamięci Narodowej”, nr 12, s. 46-53.

${ }_{97}$ Żaba do Giedroycia (8 września 1977), AIL.

98 Żaba do Giedroycia (14 czerwca 1986), AIL. W obozie niezłomnych chodzenie do ambasady PRL-u uważane było za skazę na wizerunku emigranta, tak zresztą jak i wyjazdy do Polski komunistycznej. Żaba nie należał do najbardziej pryncypialnych, ale z pewnością nie cechował go również miękki stosunek do PRL-u. Więcej na temat głównych podziałów w środowiskach emigracji politycznej w: R. Habielski (2010), Emigracja jako dyskurs, „Studia Migracyjne - Przegląd Polonijny”, r. 36, z. 2, s. 11-21.

99 Żaba do Giedroycia (14 czerwca 1986), AIL. 
Z jednej strony wyjazdy emigrantów do Polski stwarzały okazje do przerzutów nielegalnej literatury, z drugiej - niekiedy wiązały ich z PRL-em, jak pisał Żaba - „rozkładały ich ideowo” ${ }^{100}$. W czasach stalinowskich władze PRL-u prowadziły politykę ograniczania kontaktów emigracji z krajem. Od 1956 roku rząd w Warszawie próbował przyciągać emigrację zachętami do odwiedzin Polski ${ }^{101}$. W nadziei, że emigranci przywiozą do kraju dolary, ludzie ambasady oferowali im dobre kursy wymiany waluty oraz ułatwienia wizowe (po wprowadzeniu stanu wojennego znów trzeba było ubiegać się o wizy). W 1988 roku po ucieczce na Zachód Witolda Grabca, pracownika konsulatu w Sztokholmie, Żaba dowiedział się, jak zorganizowana jest praca ambasady wobec emigrantów. Placówka prowadziła kartotekę personalną - przynajmniej głównych postaci diaspory ${ }^{102}$. Na podstawie tego indeksu klasyfikowano osoby do różnych grup, starano się dzielić i rozgrywać środowisko, choć trudno na razie wyjaśnić czy skutecznie.

\section{U kresu sił}

„Byłem roztrzepany przez całe życie, pozostałem taki nawet na starość - zwierzał się Żaba Giedroyciowi ${ }^{103}$. Jego papiery - udostępnione niedawno przez Archiwum Akt Nowych - nie były prowadzone systematycznie i w sposób uporządkowany. Jest w nich wiele luk, co być może oddaje naturę Żaby - nieco chaotyczną i nieskorą do pracy papierkowej, biurowej pedantyczności. Nie pomógł tu jego przedwojenny dyplom znanej wiedeńskiej uczelni handlowej. Bałaganiarskie cechy jego charakteru przysporzyły mu kłopotów w relacjach z amerykańskimi patronami akcji rozdawniczej, ale nie na tyle, aby zaważyło to na losach tej polsko-amerykańskiej przyjaźni. Z listów Żaby wyłania się człowiek z krwi i kości - mocno wyczulony na wszelkie pretensje, na to, jak się go traktuje, przekonany o własnej wartości i wyjątkowości; wyłania się człowiek nie poddający się dyscyplinie amerykańskich biurokratów, pracujący tylko w zgodzie z własnymi przekonaniami. „Norberta Żaby jeszcze nikt nie kupił” - podkreślał ${ }^{104}$.

Przypadek Żaby powinien być rozpatrywany w kontekście umacniania więzi transatlantyckich, wciąż zbyt rzadko zauważanych przez historyków skoncentrowanych na Europie lub na Ameryce. Żaba kompensował sobie w ten sposób przerwaną karierę w dyplomacji. Niekiedy zdarzało mu się z satysfakcją odnotować,

${ }^{100}$ Ibidem.

101 Sprawa jest zawiła. Polityka ocieplania stosunków z emigracją nie dotyczyła wszystkich fal uchodźczych, np. emigracji pomarcowej raczej utrudniano kontakty z krajem jako „Żydom i syjonistom". Więcej na ten temat w: A. Kłonczyński, My..., s. 231-234.

102 Żaba do Giedroycia (7 listopada 1988), AIL.

103 Żaba do Giedroycia (12 czerwca 1970), AIL.

104 Żaba do Giedroycia (30 maja 1970), AIL. Zob. też Żaba do Rudzkiego (13 października 1980), AAN. 
że po lekturach jego klienci wracali do Polski i już inaczej myśleli. Popadał jednak również w zwątpienie. Irytował go materializm przybyszów z Polski, którzy podziwiali produkty zachodniej kultury konsumpcyjnej a nie emigracyjną kulturę. Przeszkadzał u przyjezdnych „ich cyniczny oportunizm wobec reżimu komunistycznego”. „Wierz mi - pisał do Giedroycia - tacy są w absolutnej większości”"105. W 1975 roku oceniał grono odbiorców wydawnictw wśród turystów z Polski na zaledwie 5 procent. Reszta przyjeżdżających z Polski do Szwecji miała być pozbawiona zainteresowań ideowych ${ }^{106}$. Warto uwzględnić tę cyfrę $\mathrm{w}$ ogólnym bilansie jego dokonań, oceniać akcję rozdawniczą z zachowaniem umiaru.

„Czuję wielkie zmęczenie, wieczorami niechęć do życia, wstręt do ludzi, tyle widzę warcholstwa, nikczemności, chorej ambicji albo wręcz zdrady" - w 1982 roku Żaba zwierzał się redaktorowi „Kultury”107. Rozgoryczenie jednak zamieniało się w optymizm, a okresy frustracji przeplatały się z wyjazdami nad ulubione Morze Śródziemne - do Grecji, Turcji, na Maltę, do Tunisu. Tam od razu odzyskiwał pogodę ducha. W przeciwieństwie do Giedroycia pasjonował się historią starożytną, odkrywał piękno architektury minojskiej. Jerzego uważał za mieszkańca „wieży z kości słoniowej” i zachęcał go do zwiedzania świata, choć - jak wiadomo nieskutecznie ${ }^{108}$. Żaba nie mógł się równać z Giedroyciem pracowitością. Zresztą było to tematem jego żartobliwych wyrzutów. Już w latach 70. XX wieku wróżył Giedroyciowi, że szybko wykończy się nieustanną walką o Polskę. Los sprawił, że to Żaba umarł pierwszy, w 1994 roku - sześć lat przed starszym od niego o rok wydawcą z Maisons-Laffitte.

Codzienne życie Norberta Żaby, porządkowane rytmem dystrybucji wydawnictw, wiązało go ściśle z doświadczeniami emigracji politycznej, instrumentami polityki amerykańskiej, wymianą Wschód-Zachód na obrzeżach wolnego świata. W rozmowach Żaby z przybyszami z Polski pojawiało się niekiedy uczucie utraty wspólnoty losów ${ }^{109}$. Cena, którą emigranci zwykle płacą za bycie tam, a nie tu ${ }^{110}$. Nawet to, że był w swoich wypowiedziach nieskrępowany restrykcjami politycznymi PRL-u, mogło czasami peszyć ludzi z kraju, przyzwyczajonych do innego stylu bycia ${ }^{111}$. Fragmentaryczność i niejednoznaczność źródeł tworzy grunt dla rozwoju różnych hipotez, akcentujących większe lub mniejsze znaczenie historyczne

105 Żaba do Giedroycia (17 września 1975), AIL.

106 Ibidem.

107 Żaba do Giedroycia (13 marca 1982), AIL.

108 Żaba do Giedroycia (26 września 1973), AIL.

109 Żaba do Rudzkiego (29 sierpnia 1985), AAN; Żaba do Giedroycia (17 września 1975), AIL.

${ }_{110}$ B. Schaff (2010), Paradise of Exile, w: Schaff B. (red.), Exiles, Emigres, and Intermediares. Anglo-Italian Cultural Transactions, New York: Rodopi, s. 13.

${ }_{111}$ Żaba do Giedroycia (16 sierpnia 1973, 13 lipca 1976 i 2 stycznia 1983), AIL. 
wysiłków Żaby. Mimo wątpliwości ten przypadek dostarcza źródłowego materiału teoriom, które kładą nacisk na rolę bodźców zewnętrznych w ewolucji postaw Polaków tamtych czasów i we wzmacnianiu ruchów kontestatorskich przeciw komunizmowi.

W wymiarze indywidualnym Żaba - jako kulturowy pośrednik w podzielonym świecie - dopasował formy swojej pracy społecznej do raczej skromnych emigracyjnych możliwości. W przymierzu z USA zintensyfikował dystrybucję wydawnictw emigracyjnych, dzięki czemu Sztokholm znalazł się bliżej centrum dalekosiężnych szlaków wymiany idei. Żaba musiał stawiać czoło trudnościom, wynikającym z wewnętrznych podziałów na emigracji, infiltracji wywiadu PRL-u, zimnej wojny kulturowej ${ }^{112}$. W swoich listach czasem przedstawiał siebie samego jako znawcę ludzi i świata. Służyło to nadaniu mu aury niezawodnego, godnego naśladowania działacza emigracyjnego. W obrębie wąskiego środowiska swoich współpracowników umacniał tym samym swój wizerunek jako postaci wyjątkowej - gwarantującej dobre relacje z przyjezdnymi z Polski. Być może nie zajmował aż tak centralnej pozycji. Dlatego potrzebne są dalsze badania porównawcze, który ukazałyby jego sylwetkę w bardziej złożony sposób.

\section{Bibliografia}

Basch L., Glick Schiller N., Blanc Szanton C. (1994), Nations Unbound. Transnational Projects, Postcolonial Predicaments, and Deteritorialized Nation-States, London: Routledge.

Braczyk Z. (1991), Pochwała inności. Z Norbertem Żabą, przedstawicielem „Kultury” w Sztokholmie rozmawia Zygmunt W. Braczyk, „Tygodnik Powszechny”, nr 16.

Braczyk Z. (1994), Życie na złączach. Ze wspomnień Norberta Żaby, „Acta Sueco-Polonica” nr 3, s. 217-226.

Brier R. (2013), Introduction w: Brier R. (red.), Entangled Protest: Transnational Approaches to the History of Dissent in Eastern Europe and the Soviet Union, Osnabrück: Fibre.

Freitag S. (2003), "The Begging Bowl of Revolution": the Fund-raising Tours of German and Hungarian Exiles to North America, 1851-1852, w: Freitag S. (red.), Exiles from the European Revolution: Refugees in mid-Victorian England, New York: Berghahn Books, s. 164-186.

Friszke A. (1999), Życie polityczne emigracji, Warszawa: Wydawnictwo Więź.

Garczyński-Gąssowski L. (1994), Norbert Żaba, „Gazeta Wyborcza” [„Gazeta Stołeczna”], nr 240, s. 12.

Garczyński-Gąssowski L. (2014), Wydawnictwa i rozdawnictwa w: Flis S. (red.), Emigracja a środowiska niezależne w kraju, Gdańsk-Bydgoszcz: Instytut Pamięci Narodowej, s. 64-65.

Griffiths T. (2009), Stockholm. A Cultural History, Oxford: Oxford University Press.

Grochowska M. (2009), Jerzy Giedroyc. Do Polski ze snu, Warszawa: Świat Książki, s. 375-377.

Habielski R. (2010), Emigracja jako dyskurs, „Studia Migracyjne - Przegląd Polonijny”, r. 36, z. 2, s. 11-21.

112 A. Vovinckel, M.M. Payk, T. Lindenberger (2012), Cold War Culture(s)?, w: Vovinckel A., Payk M.M., Lindenberger T. (red.), Cold War Cultures. Perspective on Western and Eastern Societies, London: Berghahn Books. 
Keck M., Sikkink K. (1998), Activists beyond Borders: Advocacy Network in International Politics, Ithaca: Cornell University Press.

Kłonczyński A. (2012), My w Szwecji nie porastamy mchem... Emigranci z Polski w Szwecji w latach 1945-1980, Gdańsk: Wydawnictwo Uniwersytetu Gdańskiego, s. 99-195.

Korek J. (2007), Norbert Żaba i „niewidzialna redakcja” o całkiem konkretnych zadaniach (zarys problematyki), w: Hofman I. (red.), Kultura paryska. Twórcy, dzieło, recepcja, Lublin: Wydawnictwo Uniwersytetu im. Marii Curie-Skłodowskiej, s. 39-53

Kowalczyk A. St. (2006), Od Bukaresztu do Laffitów. Jerzego Giedroycia rzeczpospolita epistolarna, Sejny: Fundacja Pogranicze, s. 7-13.

Kula M. (2003), Narody a migracje: esej z socjologii historycznej, „Studia Migracyjne - Przegląd Polonijny", z. 2, s. 5-13.

Kula M. (2010), Mimo wszystko bliżej Paryża niż Moskwy. Książka o Francji, PRL i o nas historykach, Warszawa: Wydawnictwo Uniwersytetu Warszawskiego.

Kula M. (2010), Najszczersze ze szczerych? Refleksje o wartości źródłowej tekstów prywatnych (na przykładzie własnych listów o własnej szkole) w: Kolbuszewska J., Stobiecki R. (red.), Historyk wobec źródeł: historiografia klasyczna i nowe podejścia metodologiczne, Łódź: Polskie Towarzystwo Historyczne, s. 185-206.

Kula W., Assorodobraj-Kula N., Kula M. (2012), Wstęp w: Kula W., Assorodobraj-Kula N., Kula M. (red.), Listy emigrantów z Brazylii i Stanów Zjednoczonych 1890-1891, PWN: Warszawa, s. 25-120.

Lyons T., Mandaville P. (2012), Introduction w: Lyons, T., Mandaville, P. (red.), Politics from Afar: Transnational Diasporas and Networks, London: Hurst and Company, s. 1-23;

McCooey Ch. (2012), Smuggling on the South Coast, Chalford: Amberley Publishing.

North M. (2016), The Baltic. A History, Cambridge: Harvard University Press.

Nowakowski T. (2013), Leksykon emigracji polskiej w Szwecji. Do 2012 roku, w: Nowakowski T. (red)., Sztokholm: Wydawnictwo Polonica.

Reisch A. A. (2013), Hot Books in the Cold War, Budapest: CEU Press

Schaff B. (2010), Paradise of Exile w: Schaff B. (red.), Exiles, Emigres, and Intermediares. Anglo-Italian Cultural Transactions, New York: Rodopi.

Sowiński P. (2011), Zakazana książka. Uczestnicy drugiego obiegu 1977-1989, Warszawa: Instytut Studiów Politycznych, s. 258.

Sowiński P. (2016), Tajna dyplomacja. Książki emigracji w drodze do Polski 1956-1989, Warszawa: Wydawnictwo Więź, Instytut Studiów Politycznych PAN.

Stöcker L. F. (2012), The Baltic Connection. Transnational Samizdat Networks between Émigrés in Sweden and the Democratic Opposition in Poland, w: Kind-Kovács F., Labov J. (red.), Samizdat, Tamizdat and Beyond. Transnational Media during and after Socialism, New York-London: Berghahn Books.

Stöcker L. F. (2014), Nylon Stockings and Samizdat. The "White Ship" between Helsinki and Tallin in the Light of its Unintended Economics and Political Consequences, "Zeitschrift für Ostmitteleuropa-Forschung", no 63.

Stöcker L. F. (2018), Bridging the Baltic Sea. Networks of Resistance and Opposition during the Cold War, Lanham, Boulder, New York, London: Lexington Books.

Sulimierski F., Chlebowski B., Walewski W. (1886), Słownik Geograficzny Królestwa Polskiego i innych krajów słowiańskich, t. 7, s. 316, Warszawa: Kasa im. Józefa Mianowskiego.

Szulc P. (2007), Zabawa w szpiega, „Biuletyn Instytutu Pamięci Narodowej”, nr 12, s. 46-53.

Tarka K. (2014), Jest tylko jedna Polska? Emigranci w służbie PRL, Łomianki: Wydawnictwo LTW. 
Vovinckel A., Payk M. M., Lindenberger T. (2012), Cold War Culture(s)?, w: Vovinckel A., Payk M. M., Lindenberger T. (red.), Cold War Cultures. Perspective on Western and Eastern Societies, London: Berghahn Books.

Władyka W. (1977), Działalność polityczna polskich stronnictw konserwatywnych w latach 1926-1935, Wrocław: Zakład Narodowy im. Ossolińskich.

Żebrowski M. (2012), Jerzy Giedroyć. Życie przed „Kultura”, Kraków: Wydawnictwo Literackie. 